\title{
With the Rise of China, What's New for Comparative Politics?
}

\author{
Zhengxu Wang ${ }^{1}$
}

Received: 5 March 2016/Accepted: 11 June 2016/Published online: 1 August 2016

(C) Fudan University and Springer Science+Business Media Singapore 2016

\begin{abstract}
The way political scientists engage with China has been more or less a one-way epistemological traffic-scholars study ideas, concepts, theories of political science, and go to China and examine the China case. Concepts or theories developed out of China studies are unlikely to become part of the standard political science lexicon. Due to the rich complexities made possible by the rise of China, this paper examines a few examples to show the promises China holds for the comparative politics field. With some fundamental changes in the field's intellectual and conceptual approaches, concepts and ideas derived from the political entity and the ongoing experience that is called China are likely to expand and revise the commonly accepted lexicon of the field. The forming of a new landscape in the field, however, will remain a process of conceptual, intellectual, and ideological contests in the decades to come.
\end{abstract}

Keywords Rise of China - Legitimacy - Chinese communist party · Comparative politics

As a sub-field in (North American) political science, comparative politics started as studies of others. In a sense, the sub-field of political theory, American politics, and probably European politics are what political science was originally all about, and the studies of politics in other parts of the world were probably an extension of the study of "proper" politics. In the European and British academia, studies of politics, and society and culture of "other parts" of the world that is, outside Europe/UK mostly belonged to the disciplines of geography and anthropology, a tradition that still defines the disciplinary structure in UK's universities today. The end of the

Zhengxu Wang

wangzhengxu@fudan.edu.cn

1 Department of Political Science, School of International Relations and Public Affairs, Fudan University, Shanghai, China 
World War II and the arrival of the Cold War increased the demand for knowledge of the Soviet Union, the Communist countries, as well as all the third world regions as they were the theatre in which the Cold War was fought. In this process, area studies acquired a significant amount of weight in the politics and sociology of knowledge production, so did the study of politics in the "areas", that is, areas outside the US. Hence the rise of comparative politics as a legitimate sub-field.

To begin this paper with this history of knowledge is to say, China came into comparative politics in the North American point of view from the periphery, and remained at the margin throughout most of the time. Today, China probably features quite predominantly in the curriculum of business schools, but in political science departments, it still takes up only a small portion of academic colleagues' attention and energy. ${ }^{1}$ As a result, until today, the discipline of comparative politics has engaged with China in a one-way epistemological exercise-scholars study ideas, concepts, theories of comparative politics, and those of political science more broadly, and go to China and examine the China case. From the field these scholars do bring back rich information and concepts that describe their case. From time to time, certain concepts and the phenomena or mechanisms they represent become well-received and they accumulate to form a body of knowledge and probably empirical theories that become the "state of the art" of the study of Chinese politics. "Fragmented authoritarianism", for example, represents such a concept that has become an important building block or even a corner stone of the field of Chinese politics.

But seldom did any concept or theory developed out of China studies go on to become part of the standard political science lexicon, and inform political studies of other regions or countries. The way for scholars to rise above the accusation of being an area study expert is to fit China in the various theoretical frameworks or paradigms in comparative politics, such as communist and post-communist studies, comparative democratization, comparative authoritarianism, civil society, and statesociety relationship, so that the China story can be told in a language that, supposedly non-China-specialist colleagues in political science departments can understand.

This paper asks whether such a one-way traffic pattern is facing revisions in the years to come. I am concerned whether there are concepts and concerns rising out of the ongoing experience that is called China that will expand and revise the commonly accepted lexicon of comparative politics. For one, given what China is, what it has been, and what has happened to it, one has to first ask whether comparative politics has done justice to the China case. I review the various paradigms that comparativists have applied to their China case, and show whether they have proved useful theoretical tools for the understanding of China. Next, as an example, I examine one critical institution in the Chinese political system, i.e., the Communist Party of China, and show how comparative politics so far has failed to make sufficient theoretical advancement in understanding the Party. Then, I present a few examples of China originated concepts and ideas that can greatly broaden our

\footnotetext{
${ }^{1}$ It is, however, reasonable to say that among all the "other" areas in the world, China receives more attention than some others, such as Southeast Asia or Africa, in comparative politics.
} 
understanding of not just Chinese politics, but politics in general. So far no such concepts have made their way into the formal political science vocabulary and toolbox. That should be the true value of comparative politics-by studying politics of the previously unfamiliar areas, we greatly improved our knowledge of human minds and human society. Against this background, I conclude by discussing how a truly globally oriented-instead of North-American centric-comparative political studies field can become possible. Or more modestly, for the comparative politics field to be able to genuinely harness the complexities made available by the rise of China, what are the necessary epistemological changes the field needs to make?

\section{Has Comparative Politics Failed China?}

The success or prominence of the China story has mainly been about its economic rise. Externally this is mostly viewed in the lens of China's expanding GDP, standing at No. 2 in the world today but predicted to become No. 1 in the near future. Together with other measurements, such as China now topping the world in trade volume, the amount of manufacturing goods produced, foreign exchange reserve, and many others, as well as energy import and carbon emission. Until the recent economic slow-down in China, it generates an image of China as an unstoppable economic giant taking the center stage of the world. Inside China, residents see the continuous increase and transformation in their living standards, $i$. e., moving into bigger apartments, eating better food, wearing fancier clothes, driving higher quality cars, traveling to farther away and more exotic places, enjoying more exciting TV, movies, concerts, and sports. The list goes on. It has, however, been extremely difficult to make sense of the political dimension of this process. As of today, the China studies field in the West still lacks a parsimonious framework to interpret China's reform and development experience since the 1980s, or to forecast its prospects. The "China Model" (Bell 2015) or "Beijing Consensus" (Ramo 2004) discourses raise more questions than they answer. Below I will show that each of the various lines of scholarship in comparative studies of politics offers some insights to the China story, but rarely do any of them prove sufficient.

\subsection{The "East Asian Miracle" Perspective}

Because of geographical and cultural proximities, when China's economy took off in the 1980s, the East Asian "tigers" that had preceded China in bringing in rapid economic growth came most naturally as the point of comparison. Indeed, it is fair to say that these East Asian economies served as the aspiration for the Deng Xiaoping leadership's commitment to economic modernization-Deng's trip to Japan and Singapore in 1978 was marked by an eagerness in developing China (Lee 2000). The diversities among the four East Asian tigers-South Korea, ROC Taiwan, Hong Kong, and Singapore-notwithstanding, the commonalities between China and them are mostly found on either the Confucian culture or the state activism in directing and promoting economic development. These commonalities, 
however, seem to stay in the economic sphere: a high saving rate, a cultural tradition emphasising education and thrift, entrepreneurship, and family-related business links, for example (Stiglitz and Yusuf 2001). Even when it comes to the state's role in economic development, China differs greatly with the "tigers", as one tiger differs with another, or Japan (more below). Once we start to talk about the political consequence of economic developments, we are confounded by an extreme level of bewilderedness. While ROC Taiwan and South Korea made a transition into a type of Western liberal democracy, we have no clue what the political outlook will be like for China (Yang 2007).

\subsection{The Developmental State Perspective}

Post-War Japanese story of economic take-off produced a big literature on how the state can proactively guide, direct, lead, promote, or manage industrialization and economic development (Johnson 1982; Woo-Cumings 1999). The general idea is valid, in that economic development indeed seems to require a self-conscious state, the visible hand in a sense. This is probably truer for late-development countries, and failures or incapacity of the state are often identified as the cause of underdevelopment in large parts of the world today (Fukuyama 2004). But the experiences and performance sheets of the various state-directed development efforts across the globe seem to vary greatly. Japan, the four East Asian tigers, and China still represent the only successful cases, with India, Brazil, Indonesia, and Malaysia etc. often identified as negative examples (Chibber 2003; Kohli 2004; Stiglitz and Yusuf 2001).

Then, the China state's role and tactics of promoting economic growth differ from those of the other successful developmental states too. In the Chinese case, the socialist legacies provide a unique endowment structure, such as the large state/collective sector, a high literacy rate, a wide array of research and academic institutions (Rawski 2009). In the end, the Chinese state's role and enabling strategies in economic development have changed since the 1980s, and work much differently from the other East Asian growth economies (Huang 2002, 2008; Montinola et al. 1995; Oi 1992; Su et al. forthcoming).

A related approach to understanding the China case is to focus on the contradictions between state-led and state-controlled development and the inability for the political system to either complete its own transition or to accommodate the changing society. In this context, the regime is known not as a developmental state, but a development autocracy (Pei 2006), or a system of developmental authoritarianism (Yang 2007). In other words, this line of inquiries generally finds it difficult to move beyond the finding that 1) the state has been developmentally successful and 2) it has maintained non-democratic rule. Everything else, i.e., regarding the future trajectory of the regime, is either speculation or assertions such as "political reform has lagged behind economic reforms." 


\subsection{The Post-Communism Perspective}

Examining China in the post-communism studies perspectives assumes a range of commonalities between China and the former Soviet Union and Eastern European countries. Indeed, a big number of China scholars were trained in such a tradition, approaching China first as another case of the communist political movement (e.g., Pei 1994). This perspective would argue the eventual collapse of the Communist ideology and its social, political, and economic systems (Dimitrov 2013; Saxonberg 2013). Furthermore, the breakdown of the Communist system would see the establishment of a new system taking the form of Western liberal democracies (Anderson 2001; McFaul 1993). A few Eastern European states, most notably Czech, Slovakia, and the three former Soviet Union's Baltic republics-Lithuania, Estonia, Latvia-have now completed this transition. In the Chinese case, it is clear that the Communist economic system has seen its termination, and its replacement by a market economic system. One can even argue that the Communist regime of social control has also faded away. Yet the political and ideological systems established since the earlier days of the Maoist time have continued, despite the evolution and refashioning of the content in the Party's official ideology. Above all, the Post-Communism perspective assumes a growing alienation between the people and the ruling Communist Party, something the China case has yet to manifest (Chen and Dickson 2008). The regime appears able to reform itself, introducing institutional changes and adaptation, giving the Party continuous, even enhanced, ability to rule (Nathan 2003; Yang 2004). Indeed, of late studies of the Party's institutionalization and institutional innovations mushroomed (e.g., Thornton 2013; Tomba 2014; He and Warren 2011; Pavlićević 2014). These innovations might represent a wave of institutionalization as the system becomes more sophisticated, but will fall short of sustaining the autocratic framework forever (Tang, N.D.). In any case, the predicted collapse of the regime has yet to materialize. With the regime continues to evolve and adapt, it is possible it stops being categorized as a Communist regime. Then, with transition out of Communism is complete in Russia and Eastern European countries, the whole Communist studies might indeed become a thing of the past.

\subsection{Comparative Democratization Perspective}

While part of the Post-Communism studies overlap with the field of comparative democratization, it is the "structural" studies of comparative democratization that are most relevant to the Chinese case. The structural conditions conducive to democratization, such as rising income and education level, forming of an urban middle class, an increasingly assertive public, and the diversification of the economic structure, etc., are indeed taking shape amidst socioeconomic modernizations in China. The likelihood of a democratic transition is increasing with the increase of per capita income (Boix and Stokes 2003; Inglehart and Welzel 2005; Wang 2008). Whether China will defy the law of gravity by maintaining a one-party political system or whether it will make the transition into democracy (in the 
current, Western definition) has become the central debating point as of late (Huang 2008; Li 2012; Rowen 2007). I myself placed a dose of faith in the human development or modernization theory of democratization, and have paid close attention to the rise of pro-democratic values and declining support for the regime in China (Wang 2007, 2008; Wang and You 2016). Yet I continue to be confronted by the "stickiness" of regime-support attitudes in China (Chen 2013), the calmness China's educated urban middle class shows toward the current political framework (Wang and Sun, forthcoming), as well as how locally vibrant politics can be separate from concern for democratization at the regime level (Wang, Liu, and Pavlićević, forthcoming 2018; Liu 2008). I have been led to think that the China case will probably lead us to rethink some very fundamental questions in political science: What is good government? What is democracy? What do political parties mean to democracy, to representation, and to political competition? Is democracy solely defined by a multiparty election? What is the "right" sequencing toward quality democracy? In the end, two to three decades from now, what is known as good government or the most preferable regime type may have acquire a different name, rending the whole comparative democratization literature a thing in the past.

\subsection{The State-Building Perspective}

State-building became a prominent topic once the political transition in the 1990s resulted in large amount of failed states or unstable democracies. David Laitin quickly predicted at the aftermaths of the September 11, 2001 terrorist attack that the future focus of political science would be "order" instead of "democracy"(Munck and Snyder 2007). Very soon, state-building, political order, governance, and governability become the concerns of political studies (Bailey and Godson 2001; Bruera 2013; Caplan 2012; Fukuyama 2004, 2011; Vigoda-Gadot 2013; Way 2005). Yet the field is mostly concerned with failures or difficulties of state building (Bates 2008), while at the same time focusing on external players' role and strategies in support state building, in places such as Afghanistan or Iraqthe Third World Quarterly, for example, designated two special issues on statebuilding in such places since 2006. There has been rather limited examination of cases of successful endogenous state-building effort in post-WWII developing world. China may in fact amounts to such a case, yet the field has paid rather little attention on how state-building is pursued in China, and what commonalities and particularities there are between the Chinese case and state-building in other countries. Yang gives a careful examination of the state's conscious effort in crafting and installing capacity-supplying state institutions (Yang 2004), but in general the China case has not featured in the general literature of state building. In other words, if state-building has been partially successful in China, we do not know what transferable lessons China can offer to the field. At the same time, the Chinese politics field's general tendency is still to analyze either state failures, in regulation, service provision, corruption, or others, or the coercive and repression parts of the state. 


\subsection{Autocracy and Authoritarian Regime}

Lastly, of late, a field of studying autocracy has been quickly forming, mostly examining institutions within autocracy or non-democratic regimes. The wave of studying democratic transition and consolidation has ebbed and autocracies are taken more seriously. In this perspective, China is not studied as a developing country or a communist regime-communism has stopped being a regime type, but is included as a type of one-party regime. This field, to me a promising one, has so far failed to be productive regarding China, however. Most studies are based on Central Asia, Middle East, North African, and Latin American regimes (e.g., Gandhi and Lust-Okar 2009; Levitsky and Way 2010; Ottaway 2002), and have given a lot of attention to elections within these regimes (e.g., Lust-Okar 2006; Morse 2012; Schedler 2006). A number of studies of China have led to the various "authoritarianism with an adjective", such as "consultative authoritarianism" (Truex 2014), "authoritarian parochialism" (Manion 2014), and "authoritarian deliberation" (He and Warren 2011). To the extent this field remains highly fragmented and skewed toward the study of certain topics (such as election) or tendency of the regimes (such as coercion instead of performance) (Tang, forthcoming), its examination of the China case has been rather rudimentary.

\subsection{China's Impact on the Field}

Besides these perspectives or traditions in comparative politics, one can also review the various concepts, models, and frameworks that have emerged out of the study of Chinese politics. To just name a few, they include "fragmented authoritarianism" (Lieberthal and Lampton 1992), "Federalism, Chinese style" (Montinola, Qian, and Weingast 1995), "Reciprocal Accountability" (Shirk 1993), Rightful Resistance (O'Brien and Li 2006), Populist Authoritarianism (Tang 2016); Decentralized Authoritarianism (Landry 2012), as well the aforementioned "authoritarianism with an adjective". Suffice to say that these researches have greatly improved the discipline's understanding of China, but it is probably difficult to assert that they have had defining impact on the field of comparative politics.

Nonetheless, the recent development in the studies of Chinese politics shows two tendencies, healthy ones in my view. The first is a rejection, or at the least downplaying of what I would call "democratic fundamentalism", in the sense students of Chinese politics have avoided viewing the Chinese case through the teleological lens of democratization. Democracy or democratic systems and processes still serve as a "significant other" of mostly implicit comparison, and continue to be present without being seen, in a sense. But the discussion is rarely framed along the line of how a transition to democracy should or would take place.

The second tendency reflects the transition of Chinese politics from a focus on (economic) development to governance. While economic development and rising income achieved through industrialization was the key element of the China story up until just recently, the challenge and objective of the state and the society is now 
a much well-rounded one. Continuing material prosperity, orderly and wellorganized social and political life, freedom and security for the individuals but at the same time belonging and community for all, among others, make up this elaborate set of objectives or demands, on the part of both the citizens and the state. The study of Chinese politics, therefore, have also moved beyond a focus of how economic development was made possible and how it has affected social groups and governance, but to look at the polity from a much larger number of angles. It is in this light I believe the China case harbors a formidable amount of complexities that can benefit the development of comparative politics as an intellectual enterprise.

\section{The Party's State and the State's Party}

The Party as a key institution in the Chinese political system would further expose the comparative politics field's shortcomings when it comes to China. The Party cannot fit in the "comparative party systems" sort of exercise. It can probably be included in a "comparative communist parties" exercise. But when the Soviet bloc was still around, the studies of communist countries generally made no distinction between the regime party and the regime-they were indeed the same thing, as the Maoist China would vindicate. Now these parties continue to rule only in four countries, all being small except for China, comparing them makes little sense. Studying the Party has become only interesting for the study of China. A few promising works have emerged (Brodsgaard and Zheng 2006; Pieke 2009; Shambaugh 2008), but the field still needs a much fuller effort to examine the Party, from the following perspectives, for example:

- Ideology The Party's belief that it governs to deliver benefits to the largest majority of the people, together with its evolving guiding principles, such as the Scientific Development and Harmonious Society Concepts, toward such as goal. Does such a belief and ideological consciousness define the Party? How is such a belief system operationalized in various aspects of the Party's work? How is such a belief system comprised or upheld in the actual political and governing processes?

- Recruitment, gate keeping, and self-cleansing How does the Party target the most talented and most capable members of the society, and recruit them into the Party? How does it prevent sub-quality aspirants from sneaking into the Party? How does it locate low-quality members and remove them from its rank and file?

- Indoctrination, development, and promotion of members how does the Party ensure its rank and file are on the same page with Party thinking? How does it equip its members with the ability and skills necessarily for running the economy and managing the society? How does it identify the competent ones for further development and promotion?

- Learning, adaptation, and self-renewal How does the Party learn about the social realities it finds itself in? How does it understand what changes are needed 
in terms of structure, institutions, policies of party-building? How does it enable such changes?

- Governance How does it understand the policy needs of the society? How does it understand what policy responses are needed for the various social, political, and economic issues that are emerging each day? How are different policy proposals formulated, deliberated on, and adopted? How are they implemented?

In general, the studying Chinese politics scholars have paid much more attention to the societal actors or processes, such as the civil society and protests, or the lower layers of the state, such as village, township, and municipal governance. That is probably due to the accessibility of the research subject, which makes the partystate's higher level or more closed elements difficult to study. In any case, the Chinese politics field lacks good studies of the Party and the state, and the study of the Chinese Party and the state is badly integrated in comparative politics.

Then it is not just about the Party. It is about the Party in relation to the state, and the Party in relation to the citizenry and the society. But in the Chinese case, the state functions as a subsidiary of the Party, in the sense that each level of the state hierarchy is directed by the Party Committee, which is in turn directed by the Party Committee one- or two-level above. While the state formally operates as an executor of Party decisions, some Party decisions are executed by the Party's own agencies. The picture is even more complicated because the various offices, bureaus, and agencies of the state are staffed by the members of the Party, who are subject to the Party's policy, ideological, and organization influences day in and day out. The Party's relationship to the society is equally complicated. The Party, by itself, promises to be a highly rewarding subject for ambitious comparativists. ${ }^{2}$

\section{The Power of Ideas}

The problem with comparative politics' approach to China is that, scholars so far are trained in a set of ideas, theories, and conceptual frameworks developed in the North America, and take these to study China. Scholars coming to China (outside-in) often lack the appreciation of indigenous ideas and concepts. With the rise of China, it is highly likely the ideas and concepts originated in China will become legitimate subjects for comparativists to reckon with. This section gives a few of such examples.

The idea of legitimacy of a political regime, for example, is alien to the Chinese mind. The Chinese mind can probably understand the idea of "the right to rule", but that is not quite the same meaning of "legitimacy", and "the right to rule" is not proper in Chinese political thought in any case. If "legitimacy" is translated into Chinese as “hefaxing, 合法性”-literally, the legalness-it requires quite a few

\footnotetext{
2 The Confucian Party or the Communist Party-As revolutionary party, it was born out of the Western/modern Lenenist Idea. But very soon it pick up or remodel itself with the Confucian scholarbureaucracy type. Is the Party the contemporary incarnation of the educated Confucian scholarly class?a common identity, a common ideological system, and common set of beliefs, and a rather elaborate system of career management and role assignment and role modification?
} 
number of steps to be able to link to the idea of legitimacy in Chinese political philosophy. In trying to examine the sources of legitimacy of the Chinese regime, scholars versed in Chinese political thoughts have pointed to Chinese concepts that represent the idea of legitimacy much better in the Chinese context. Yun-han Chu, who directs the Asian Barometer survey that tracks the development of democratic governance in East Asia, argues that the high level of legitimacy enjoyed by the Chinese regime is due to its delivering a "for the people" government. Because it lacks direct and competitive elections, according to Western norms this system fails the "by the people" and "of the people" criteria of a democracy. Nevertheless, as long as it maintains its "for the people" purpose and strength, the system can enjoy sustainable public support (Chu 2009, 2013). This "for the people" dimension of Lincoln's democracy legitimacy troika is known in Chinese as minxiang, which if translated back into English stands for the government that is "enjoyed by the people". ${ }^{3}$ In other words, it emphasizes the outputs of a political system that citizens perceived as delivered to the people and perceived as satisfactory by the people. The Confucian political philosophy of minben-ism, literarily treating the people as the roots of state policies, does suggest that the people look upon the government as benevolent and omnipotent, a political culture that lead the people to place legitimacy on the paternalistic state. Empirical research has established that the Chinese public judges the system's legitimacy according to their ideas of substantive democracy, instead of the procedures (Shi and Lu 2010). This echoes findings from the Scandinavia literature that citizens grant legitimacy to government institutions not because they are based on certain "right" procedures but because they deliver (Rothstein 2009).

Peking University academic Pan Wei, a comparativist trained in UC Berkeley, provides a purely Chinese conception of regime legitimacy. Ideationally, Pan argues that Chinese conception of legitimacy lies in the belief in minxin. Literarily translated as "people's heart", minxin actually means much closer to a combination of people's heart, faith, support, allegiance, submission, and more (Pan 2009). Minxin cannot be directly measured by opinion polls, because individual citizens are confined by their short-term and immediate interests. The sum of the atomized individuals is not the collectivity. Minxin needs to be understood by the intellectual and political elites, who take a broader, longer-term and more balanced perspective when assessing the people's needs and the interests of the whole political community. A regime that accurately understands the people's needs and interests, and makes policy choice according to such needs and interests, commands minxin and hence enjoys legitimacy. ${ }^{4}$ Hence, ideationally, Chinese or Confucian political philosophy legitimates a system by its results. So whether the regime performs renzheng (governance of compassion or humanity) for the people (weimin) can be judged by the level of "minxin" it is able to command.

\footnotetext{
${ }^{3}$ The other two criteria are known in Chinese as minyou (of the people) and minzhi (by the people), respectively, which if translated back to English stands for "owned by the people", and "governed or run by the people", respectively.

${ }^{4}$ The one who commands people's heart commands the world—de minxin zhe de tianxia —is the original saying. In a sense, minxin might be a better translation of the term legitimacy than other newly constructed terms such as hefaxing or zhengdangxing.
} 
Pan Wei goes on to argue that procedurally, the institutional design of the Chinese system, which he calls min zhengzhi (people-based politics), also demonstrates legitimacy. In a nutshell, he argues that because "the people" is a collective body, it should be represented holistically. The Western way of organizing politics through competitions between parties and interest groups only succeed in dividing society and representing a fraction with the winner of any election representing only one portion, and sometimes a minority, of the citizens. ${ }^{5}$ Because electoral institutions based on a competing party system cannot represent the best interests of the people, Pan Wei argues that the legitimate way should be selecting the better-educated and more capable people with vision and personal integrity to run the government. In this regard the current CCP conception of the Party as the elite portion of the people (the term used is xianfengdui, or vanguard in English) mirrors nicely the Confucian conception, in which learned people naturally become officials, whose obligation is to produce good governance for the baixing (people).

In this regard, we have two approaches to the relationship between ideology and legitimacy in China as a communist or post-communist regime. According to Saxonberg's (2013) topology, after its totalitarian stage, a communist regime will evolve into an early and then a maturing post-totalitarian stage. In this process, the regime will gradually lose its ideological legitimacy, which is specifically due to its economic developments and political failures. At this stage, the regime stays in power only because it is able to secure the public's "pragmatic acceptance" by delivering a reasonably high standard of living, while the workers and peasants choose not to revolt due to the potential risks of repression and loss of socioeconomic stability. Such a theory therefore, echoes with a wide range of work that sees the Chinese regime as ideologically delegitimized but remaining capable of "buying" loyalty from the public by delivering acceptable levels of governance outputs (See chapters in Dimitrov 2013). In any case, this line of argument sees the communist regime as eventually losing its ability to legitimatize itself by its original (Marxist-Leninism) ideology, upon which point it collapses (Dimitrov 2013). A competing line of argument, however, sees some of the communist regimes as being able to renovate and reinvent the ruling ideology, and continues to manufacture its ideological legitimacy and command inner-party coherence. The Chinese Communist Party's ideological evolution since the 1980s can be a case in point, in which the Party advanced its post-Mao ideological reformation in the forms of Deng Theory, The Three Represents, and the Scientific Concept of Development (Holbig and Gilley 2010). Such ideological reformation, however, are viewed by other scholars as parts of political reform that merely extend the duration of the regime, instead of ensuring its continuous renewal (Dimitrov 2013). The minxin theory advanced by Pan, and the minxiang, for-thepeople theory advanced by $\mathrm{Chu}$, however, offers a fundamentally different perspective. Instead of seeing the Chinese regime as being able to renew its

\footnotetext{
5 When attending an election rally in Taiwan before the 2004 presidential election, on seeing that the Taiwan electorate was sharply divided along the sub-ethnical lines, sociologist Andrew Walder commented that elections were the best way to divide a society-relayed by Dr. Litao Zhao in a personal communication.
} 
ideological discourse from its Marxist-Leninist origin, these scholars argue that the Chinese regime bases its legitimacy discourse on a completely different intellectual source, the Confucian political philosophy, viably operating through China's more than 2000 years of political experience, despite a brief interruption at the official level between 1949 and 1978.

Plenty of similar examples can be found in Chinese political thoughts and philosophy in general. The Chinese idea of zhongyong 中庸, wangdao 王道, zhengdao 政道, among others, are yet to be articulated in languages understandable to non-Chinese minds, let alone to be operationalized into researchable questions or measurements. Sang Yucheng, a highly seasoned and reputable academic at Fudan University's Department of Political Science, for example, recently raised three Chinese characters as possessing tremendous power providing the perspectives and wisdom for human life and public affairs (Sang 2016). The ideas related to rong 容、 $d u$ 度, and lei 类 are too rich to be explained here, but my point here is how a dialogue about two political systems (i.e., comparative studies of political system) can become meaningful if some fundamental ideas behind the design and construction of the two systems are not understood by the persons having such a dialogue. Can empirical studies of politics in a different political system generate genuine knowledge when the political scientist lacks understanding of the meanings of politics, human society, and human life at such a deep-root level?

\section{Toward a global field of comparative politics?}

From an American political science point of view, comparative politics regards American scholars' attempt to understand politics in other parts of the world, as well as the attempt to analyze such politics of "other parts of the world" with a unified conceptual framework. The study of American politics itself, and that of political theory, are separate from this epistemological exercise. Yet with the globalization of the field of comparative politics, scholars outside the US might be actively creating a field less affected by this North American bias. North America, of course, remains the center of social science enquiry, and will continue to define, lead, and shape the global field of comparative politics in the years to come. Conferences held in the North America, political science journals edited by American professional associations, and comparative politics scholars based in the North America, will continue to hold the power, some may even say hegemony, in the production of ideas, concepts, and theories, as well as innovation in methods in comparative politics.

In this regard, the rise of China may bring changes in several areas. First, the volume of academic outputs produced in China will increase quickly. The political science departments inside China, with their increasing number of colleagues capable of publishing in English-language journals, an increasing number of whom having been trained in North American political science departments, will deliver this change (e.g., Tang et al. 2015; Zeng 2015; Zuo 2015). Second, academic exercises conducted in China will increase rapidly, with more and more Chinese universities or professional associations holding academic conferences and running 
English-language journals. Third, the China case will feature much more prominently in the comparative politics scholarship, and either implicitly or explicitly, China will be more frequently compared with the US and the so-called "advanced industrial countries" in the field of comparative politics.

These structural changes in the production of comparative politics scholarship will lead to changes in the substance of comparative politics. To harness the complexities made available by the rise of China will be the most challenging but also most promising intellectual and professional exercise of students of comparative politics and students of political science in general. As the examples explored briefly in this paper can show, whether in terms of some of the first questions regarding human life and social and public affairs, how politics is organized and exercised, and how politics will evolve in the years to come, China harbors tremendous richness waiting to be discovered. With the structural changes in knowledge production in comparative politics, some of these complexities will be discovered and organized and presented to the field, in ways and forms familiar to the so far North America-defined field.

But to fully harness these rich complexities, the so far North America led field needs a fundamental shift in the philosophy of knowledge. The positivist and scientistic approach to comparative politics is fine, but in social science for most of the time we are positivist and scientistic only at the lower, empirical level, while our research and perspectives develop within a cage or box that is ideology or value system. Too often we believe we are approaching the world on behalf of or guided by a set of universal values. To this student of the world, universal values do exist but at the ontological level, and intellectuals, scholars, philosophers take it upon them to get to them, formulate them into linguistic expressions, and communicate them to the world. Therefore, "universal values" or concepts articulated by any individual scholar or intellectual tradition must always be relative, local, and partial. And the arrival at the set of commonly agreed "universal" values must always be a process of contests, communication, and negotiation.

Therefore, for most of the cases, the set of values that have indoctrinated any individual scholar or knowledge worker are also such relative, local, and partial values. The concepts that we operationalize and turn into measurable variables when we try to understand politics of "other parts" of the world, therefore, are unavoidable based on some local or partial values or "truth". To this student of comparative politics, the challenge for a researcher to be truly global/universal comparativist is to realize this two-level nature of values and our knowledge. Only with a truly global/ universal perspective, can a researcher be able to take the advantages presented by the complexities made newly available by the rise of a new center of social, political, and human activities in the world. The future of comparative politics will see the mainstreaming of concepts, ideas, and stories originated from or taking place in China, and China as a social and political entity, a process, and an ongoing practice can even lead to revision of, not merely words, terms, and language, but faith of the discipline. While China's rise is likely to greatly expand and enrich the ideas and perspectives of comparative politics, the forming of a new landscape of the field in the future decades will remain a process of intellectual, political, and ideological contests. 


\section{References}

Anderson, Richard (ed.). 2001. Postcommunism and the theory of democracy. Princeton: Princeton University Press.

Bailey, J.J., and R. Godson. 2001. Organized crime and democratic governability: Mexico and the U.S.Mexican borderlands. University of Pittsburgh Press.

Bates, R.H. 2008. State failure. Annual Review of Political Science 11: 1-12.

Bell, Daniel A. 2015. The China model: political meritocracy and the limits of democracy. Princeton, NJ: Princeton University Press.

Boix, Carles, and Susan C. Stokes. 2003. Endogenous democratization. World Politics 55(3): 517-549.

Brodsgaard, Kjeld Erik, and Yongnian Zheng, eds. 2006. The Chinese communist party in reform: Routledge.

Bruera, H.F.G. 2013. Lula, the Workers' Party and the Governability Dilemma in Brazil. Taylor \& Francis.

Caplan, R. 2012. Exit Strategies and State Building. OUP USA.

Chen, Jie. 2013. A middle class without democracy: Economic growth and the prospects for democratization in China. New York: Oxford University Press.

Chen, Jie, and Bruce J. Dickson. 2008. Allies of the state: Democratic support and regime support among China's private entrepreneurs. The China Quarterly 196: 780-804.

Chibber, Vivek. 2003. Locked in place: State-building and late industrialization in India. Princeton: Princeton University Press.

Chu, Yun-han. 2013. Sources of regime legitimacy and the debate over the chinese model. China Review 13(1): 1-42.

Chu, Yun-han. 2009. Zhongguo Muoshi yu Quanqiu Chixu Chongzu [The China Model and the Reorganization of the World Order]. In China model: a new developmental model from the sixty years of the People's Republic, ed. Wei Pan, 603-630. Beijing: Central Compilation \& Translation Press.

Dimitrov, Martin K. (ed.). 2013. Why communism did not collapse: understanding authoritarian regime resilience in Asia and Europe. New York: Cambridge University Press.

Fukuyama, Francis 2004. State-building: Governance and world order in the twenty-first century London: Profile Books.

Fukuyama, Francis. 2011. The origins of political order: from prehuman times to the French revolution. Profile Books.

Gandhi, Jennifer, and Ellen Lust-Okar. 2009. Elections under authoritarianism. Annual Review of Political Science 12: 403-422.

He, Baogang, and Mark E. Warren. 2011. Authoritarian deliberation: the deliberative turn in Chinese political development. Perspectives on Politics 9(02): 269-289.

Holbig, Heike, and Bruce Gilley. 2010. Reclaiming Legitimacy in China. Politics \& Policy 38(3): 395422.

Huang, Yasheng. 2002. Selling China: Foreign direct investment during the reform Era. of Cambridge Modern China Series. New York: Cambridge University Press.

Huang, Yasheng. 2008. Capitalism with chinese characteristics: entrepreneurship and the state. Cambridge University Press.

Inglehart, Ronald, and Christian Welzel. 2005. Modernization, cultural change, and democracy: The human development sequence. Cambridge: Cambridge University Press.

Johnson, Chalmers Ashby. 1982. MITI and the Japanese miracle: The growth of industrial policy, 19251975. Stanford: Stanford University Press.

Kohli, Atul. 2004. State-directed development: Political power and industrialization in the global periphery Cambridge. UK: Cambridge University Press.

Landry, Pierre F. 2012. Decentralized authoritarianism in China: The Communist Party's Control of Local Elites in the Post-Mao Era. Cambridge University Press.

Lee, Kuan Yew. 1998. The singapore story: memoirs of Lee Kuan Yew. Singapore: Singapore Press Holdings.

Lee, Kuan Yew. 2000. From third world to first: the Singapore Story, 1965-2000: memoirs of Lee Kuan Yew. Singapore: Singapore Press Holdings.

Levitsky, S., and L.A. Way. 2010. Competitive authoritarianism: Hybrid regimes after the cold war. Cambridge University Press. 
Li, Eric X. 2012. The life of the party. Foreign Affairs 92: 1.

Lieberthal, Kenneth, and David M. Lampton. 1992. Bureaucracy, politics, and decision making in postMao China (Studies on China). vol. 14, Berkeley, CA: University of California Press.

Liu, Chunrong. 2008. Empowered autonomy: The politics of community governance innovations in Shanghai. Chinese Public Administration Review 5(1-2): 61-71.

Lust-Okar, Ellen. 2006. Elections under authoritarianism: Preliminary lessons from Jordan. Democratization 13(3): 456-471.

Manion, Melanie. 2014. Authoritarian parochialism: Local congressional representation in China. The China Quarterly 218: 311-338.

McFaul, Michael. 1993. Transitions from postcommunism. Journal of Democracy 16(3): 5-19.

Montinola, Gabriella R., Yingyi Qian, and Barry R. Weingast. 1995. Federalism, Chinese style: The political basis for economic success in China. World Politics 48: 50-81.

Morse, Yonatan L. 2012. The era of electoral authoritarianism. World Politics 64(01): 161-198.

Munck, G.L., and R. Snyder. 2007. Passion, craft, and method in comparative politics. Johns Hopkins University Press.

Nathan, Andrew J. 2003. Authoritarian resilience. Journal of Democracy 14(1): 6-17.

O'Brien, Kevin J., and Lianjiang Li. 2006. Rightful resistance in rural China. New York and Cambridge: Cambridge University Press.

Oi, Jean C. 1992. Fiscal reform and the economic foundations of local state corporatism in China. World Politics 45(1): 99-126.

Ottaway, Marina. 2002. Democracy challenged: The rise of semi-authoritarianism. Washington, DC: Carnegie Endowment for International Peace.

Pan, Wei. 2009. Dangdai Zhonghua Tizhi [Contempory Chinese Institutions: An economic, political, and social analysis of the China Model]. In China model: a new develomental model from the sixty years of the People's Republic, ed. W. Pan, 3-85. Beijing: Central Compilation \& Translation Press.

Pavlićević, Dragan. 2014. Public participation, state building and democratization in China: nonelectoral participatory mechanisms in Zhejiang. Ph.D Thesis, Nottingham: University of Nottingham.

Pei, Minxin. 1994. From reform to revolution: The demise of communism in China and the Soviet union. Cambridge, MA: Harvard University Press.

Pei, Minxin. 2006. China's trapped transition. Cambridge, MA: Harvard University Press.

Pieke, Frank N. 2009. The Good Communist: Elite Training and State Building in Today's China. Cambridge University Press.

Ramo, Joshua Cooper. 2004. The Beijing Consensus. London: The Foreign Policy Centre.

Rawski, Thomas G. 2009. "Is China's Development Success Transferable?," University of Nottingham China Policy Institute Discussion Papers (49).

Rothstein, Bo. 2009. Creating political legitimacy: Electoral democracy versus quality of Government. American Behavioral Scientist 53(3): 311-330.

Rowen, Henry S. 2007. When will the Chinese people be free? Journal of Democracy 18(3): 38-52.

Sang, Yucheng, 2016, "Three Chinese Characters" for the Tao of Human Life and Public Affairs. Jiefang Daily.

Saxonberg, Steven. 2013. Transitions and non-transitions from communism: Regime survival in China, Cuba, North Korea, and Vietnam. New York: Cambridge University Press.

Schedler, Andreas. 2006. Electoral authoritarianism: The dynamics of unfree competition. Lynne Rienner Publishers, Inc.

Shambaugh, David. 2008. China's communist party: Atrophy and adaptation. Washington, DC: Woodrow Wilson Center Press.

Shi, Tianjian, and Lu Jie. 2010. The shadow of confucianism. Journal of Democracy 21(4): 123-130.

Shirk, Susan L. 1993. The political logic of economic reform in China Berekeley and Los Angeles. CA: University of California Press.

Stiglitz, Joseph E., and Shahid Yusuf, eds. 2001. Rethinking the east Asian miracle. Washington, DC; New York: World Bank; Oxford University Press.

Tang, Wenfang. 2016. Populist authoritarianism: Chinese political culture and regime sustainability. New York: Oxford University Press.

Tang, Min, Narisong Huhe, and Qiang Zhou. 2015. Contingent democratization: When do economic crises matter? British Journal of Political Science (Published Online). doi:10.1017/ S0007123415000095. 
Tang, Shiping. Autocracy: Toward an integrated and dynamic analytic framework. Manuscript (forthcoming).

Thornton, Patricia M. 2013. The advance of the party: Transformation or takeover of urban grassroots society? The China Quarterly 213: 1-18.

Tomba, Luigi. 2014. The government next door: Neighborhood politics in urban China. Ithaca, New York: Cornell University Press.

Truex, Rory. 2014. Consultative authoritarianism and its limits. Comparative political studies: 0010414014534196.

Vigoda-Gadot, P.E. 2013. Building strong nations: Improving governability and public management. Limited: Ashgate Publishing.

Wang, Zhengxu. 2008. Democratization in confucian East Asia: Citizen politics in China, Japan, Singapore, South Korea, Taiwan, and Vietnam. Youngstown: Cambria Press.

Wang, Zhengxu, Jianxiong Liu, and Dragan Pavlićević. 2018. Democratic Localism. China: An International Journal (forthcoming).

Wang, Zhengxu, and Yu. You. 2016. The arrival of critical citizens: Decline of political trust and shifting public priorities in China. International Review of Sociology 26(1): 105-124.

Wang, Zhengxu, and Long Sun. Social class and voter turnout in China: Local congress elections and the citizen-regime relations. Political Research Quarterly (forthcoming).

Way, Lucan. 2005. Authoritarian state building and the sources of regime competitiveness in the fourth wave: The cases of Belarus, Moldova, Russia, and Ukraine. World Politics 57(2): 231-261.

Woo-Cumings, Meredith (ed.). 1999. The developmental state. Ithaca: Cornell University Press.

Yang, Dali. 2004. Remaking the Chinese leviathan: Market transition and the politics of governance in China. Stanford: Stanford University Press.

Yang, Dali (ed.). 2007. Discontented miracle: Growth, conflict, and institutional adaptations in China. Edited by Joseph Fewsmith and Yongnian Zheng, Series on Contemporary China. Singapore: World Scientific Press.

Zeng, Qingjie. 2015. Democratic procedures in the ccp's cadre selection process: Implementation and consequences. The China Quarterly 2015: 1-27.

Zuo, Cai Vera. 2015. Promoting city leaders: The structure of political incentives in China. The China Quarterly 224: 955-984.

Zhengxu Wang Ph.D. is Shanghai 1000-Talent Distinguished Professor and Shanghai Oriental Scholar at the Department of Political Science of Fudan University's School of International Relations and Public Affairs (SIRPA). His research interests include comparative democratization, institutions in authoritarian regimes, political values and attitudes of citizens in modernizing societies. 